\title{
LONG-TERM PRINCIPLE CONCEPT FOR SUSTAINABLE DEVELOPMENT OF COASTALZONE MANAGEMENT
}

\author{
ELENA VITKIENÉ ${ }^{1}$ \\ Klaipeda University (Lithuania)
}

\begin{abstract}
The long-term principle concept is based on setting and achieving a vision for the future of coastal zone management. The vision for the sustainable development of coastal zone management includes utilizing new advances in scientific, technical, social and economic understanding of coastal sustainability. The coastal environment, dunes and beaches are outstanding natural assets. Their wildlife, cultural, historical and archaeological resources should be passed on to future generations in similar or better conditions than they are currently. The principle of long-term management can be analyzed according to these definitions (economics, ecology, ethics) concepts: comprehensive overview of systems, detailed investigation of issues, and the planning development of management practices that have a positive effect on the future. KEYWORDS: coastal zone, integrated socioeconomic responsibility, long-term principle concept, sustainable development.
\end{abstract}

JEL CODES: M000, O200, Q010, Q540, Q550

\section{Introduction}

Financial crisis in the global economy, climate change and a lack of positive action has too often led to the destruction of much of our coastal zone - coastal areas, cultural heritage and landscape. These factors have often been exacerbated by poor coastal protection and conservation management, and at times by neglect.

The methods of protection and conservation used on these coastal zones - dunes and beaches followed the preservation measures instructed by Natura 2000, European Commission (2000). These included the erection of sand-retaining fences made of brush and wattle, and the use of special sand. While these actions appear at first glance to have merits, it is evident that the construed plan and the precautionary measures intended to address concerns along the coastal zones and dunes were entirely ineffectual. In fact, with these scant methods of preservation, the damage caused during the strong winds were inevitable.

Clearly, the erosion caused by this powerful force of nature could have been prevented by carefully designed out plans for long-term preservation. Specifically, the use of a combination of multifunctional methods: safe, simple and economical measures that recall past experience and utilize reliable practices.

Changing nature and climate conditions, strong winds cause significant damage throughout the world and along the European coast. For example, the dunes and beaches of Palanga (resort of Baltic Sea, near Klaipeda Sea Port in Lithuania) are being increasingly eroded by repeated battering, such as was inflicted during the January 2007 hurricane "Ervin" and this bringing down process has been dragging on for every year up to now. Despite the investment of millions Euro in the past years towards the protection of Palanga's natural dunes and beaches, the use of outdated technologies and ineffective precautionary measures proved inadequate.

\footnotetext{
Elena Vitkienè - Klaipeda University, Faculty of Social Sciences, Department of Economy, Prof. dr. Scientific interests: EU Regional Management Strategy, Service Economics and Marketing, Integrated Socioeconomic Responsibility.

E-mail: elena.vitkiene@gmail.com

Tel.: +730698017 76 .
} 
In fact, the global economy crisis, the natural environment, coastal cultural heritage and landscape values are influenced by decision-making and economic conditions elsewhere. Protected natural areas, coastal heritage sites and landscapes are very attractive settings for the growing demand for outdoor recreation and leisure activities in natural environments.

Over 200 years ago, Adam Smith concluded that international exchange of goods was a source of greater wealth for all countries. Trade provides the possibility of increasing specialization and better utilization of each country's natural resources.

Coastal management has come a long way in the past 35 years, and if we want to ensure a stable future, we would do well-timed to remember the past, according to Aurelian Augustine (Philosopical..., 1980). Therefore, it is essential to review history before beginning the planning process. This perspective will enable critical thinking about the current conditions of coastal zones - coastal areas, dunes and beaches, and will provide a foundation from which we can establish intentionally long-term environmental and financial principles. Hence, it is valuable to remember and review the conclusions of several international conferences and symposium, especially the following: Littoral '96 (Portsmouth, UK), Coastal Zone '97 "The Next 25 Years" (Boston, Massachusetts, USA), Littoral '98 (Barcelona, Spain), Littoral 2002 (Porto, Portugal), Littoral 2004 (Aberdeen, Scotland, UK), Dunes \& Estuaries 2005 (Koksijde, Belgium), ICCCM '05 (Tavira, Portugal) and Littoral 2006 (Gdansk, Poland). These international conferences, symposiums, meetings, and practical workshops, along with the LIFE-Nature project "FEYDRA" (Dunes \& Estuaries, 2005, Koksijde, Belgium), and important field trips in the coastal area region of Algarve (ICCCM'05, Algarve, Portugal), provide essential experience suited to raising awareness among European nations at the national, regional and local levels.

These international conferences and strategic plans were excellent opportunities to evaluate the past, assess the present and plan for the future. The 1997 Coastal Zone Conference (Boston, USA) created a plan for the next 25 years, and especially the "Dorset Coast Strategy" (Brunsden, 1999, UK), where was set out a strategic coastal plan that extends to 2050, with a vision for many more years.

The problem of this article is lack of understanding the meaning of the long-term principle concept of integrated responsibility and of the sustainable development of coastal zone - coastal areas management strategy.

The purpose of this research is to establish a basis of thinking about the sustainable development of coastal zone - coastal areas management in terms of long-term principle concept.

The object of the study is long-term principle concept for the coastal zone coastal areas sustainable development for coastal zone - coastal areas management strategy.

The tasks of the research are the following:

- to analyze and generalize theoretic and practical aspects of the coast zones - coastal areas management problems;

- to introduce the long-principle principle concept model of integrated responsibility in the coastal zone - coastal areas management strategy

- to prepare and to present purpose - model of the hierarchy of goal - setting activities of the long-term principle concept of coastal zone - coastal areas management for sustainable development.

Therefore, the principal task was to present this model, which is grounded in the perspective of sustainable, long-term practices that acknowledge the past, but look forward to future renewed.

The methods of this article are analysis and generalize scientific literature and practical material issues concerning coastal zone - coastal areas management and sustainable development problems.

Also the research used a descriptive and synthesis methods, which helped to present the purposeful model of the long-term principle concept of integrated responsibility in the coastal zone - coastal areas management strategy, and to prepare and to show the model of the hierarchy of goal - setting activities of the long-term principle concept of coastal zone management strategy for sustainable development.

In order to experience growth in the appreciation of coastal culture and landscape values, long-term strategies must include the integration of socio-economic (economic, ecological and ethical) responsibilities. Within the European Union, it is necessary to formulate responsible, cooperative approaches that are com- 
mitted to long-term results. Both empirical and practical evidence demonstrate that the sustainable development of effective coastal zone management policies includes the integration of responsible socio-economic practises. The long-term principle concept is a philosophy of integrated coastal zone management which mandates that all activities has to be oriented towards long-term practises that protect our natural resources.

\section{Some theoretical and practical materials considerations}

Fundamental documents (European Commission, 2000), several authors (Cole, 1994; Hoffman and Moore, 1990; Goodhead and Johnson, Pickering, Taussik, 1996; Pickaver and Salman, 2006; Kotler, et al., 2001) utilized multidisciplinary approaches that unify methods from several different disciplines (i.e. ethics, economics, philosophy, strategic management, marketing, ecology and coastal recreation management). This approach allows for examination of coastal zone management problems from a various aspects, thereby leading to a more comprehensive view of the issues and the ability to formulate holistic practices for longterm environmental protection.

In addition, strategic management theory and practise (Cole, 1994: 31), and analysis of strategic planning (Kotler, 2001: 96-97), the theory and practice of coastal recreation management, coastal management plans by D. Johnson (1996: 273-395) and the term "development plan" by J. Taussik (1996: 115-137), also strategies at national, regional and local levels will have a time horizon of at least 15 years. In the some place investigations are connected with coastal conservation and management (Gomes, et al., 2005), nature restoration practices in European coastal habitats (Herrier, et al., 2005), also M. C. Miller and J. Cogan (1997), J. Taussik and J. Mitchel (1996), and investigations assigned to a coastal innovations and initiatives (Tubielewicz, 2006), coastal areas socioeconomic value (Forkiewicz, Tubielewicz, 2006), discusses coastal zones - coastal areas management from new approach to harbour, coastal research, environmental risk problems, risk management, innovative concepts for coastal protection and education (Forkiewicz, 2006).

All these theoretical and practical considerations are important for establishing environmental sustainability, and for making critical choices among the various alternate strategies. They also assist in the construction of realistic timelines, in the implementation of effective long-term economic measures, and in creating appropriate means to test and evaluate plans. These approaches provide a critical structure to the initial development of a vision for integrated coastal zone management, as well as for the ongoing view of the future.

Complex and significant ethical, economic, sustainable development and management decisions are made based on the situation at any given time. The components of the long-term principle concept are include goals, methods, motives and consequences as they relate to integrated socio-economic management in global, European, national, regional and local coastal areas.

\section{Long-term principle concept of the integrated responsibility}

Indispensable to the sustainable development of integrated coastal zone management is the creation of long-term principles that encompass main components: economic, ecological and socio-ethical. Figure 1 presents a model of long-term principles of integrated responsibility of coastal zone management strategies, as prepared by the author.

Economic responsibility. One basic supposition of the long-term principle is that economic responsibility must be utilized to the greatest possible benefit, and that ultimately "short-term projects need to be replaced by long-term programmes" (Pickaver and Salman, 2006: 12). Long-term financing is critical to sustaining ongoing programmes, and for providing support for new technologies.

Ecological responsibility. Ecological responsibility is the main priority in developing long-term strategies for regional and national environmental management. Opinions regarding the relationship between humans and nature can be revealed in two differing moral trends: ecocentric views and anthropocentric views. Ecocentrism raises the question: does human moral responsibility for nature exist?

Ethical/Social responsibility. Proponents of ecocentrism acknowledge the importance of the entire ecosphere, whether animate or inanimate. In contrast, anthropocentrism, which adheres to human domina- 
tion over nature, essentially dismisses the need for such questioning. Increasingly, ecocentrists are demanding responsibility from society, and action that preserves nature rather than caters for humanity.

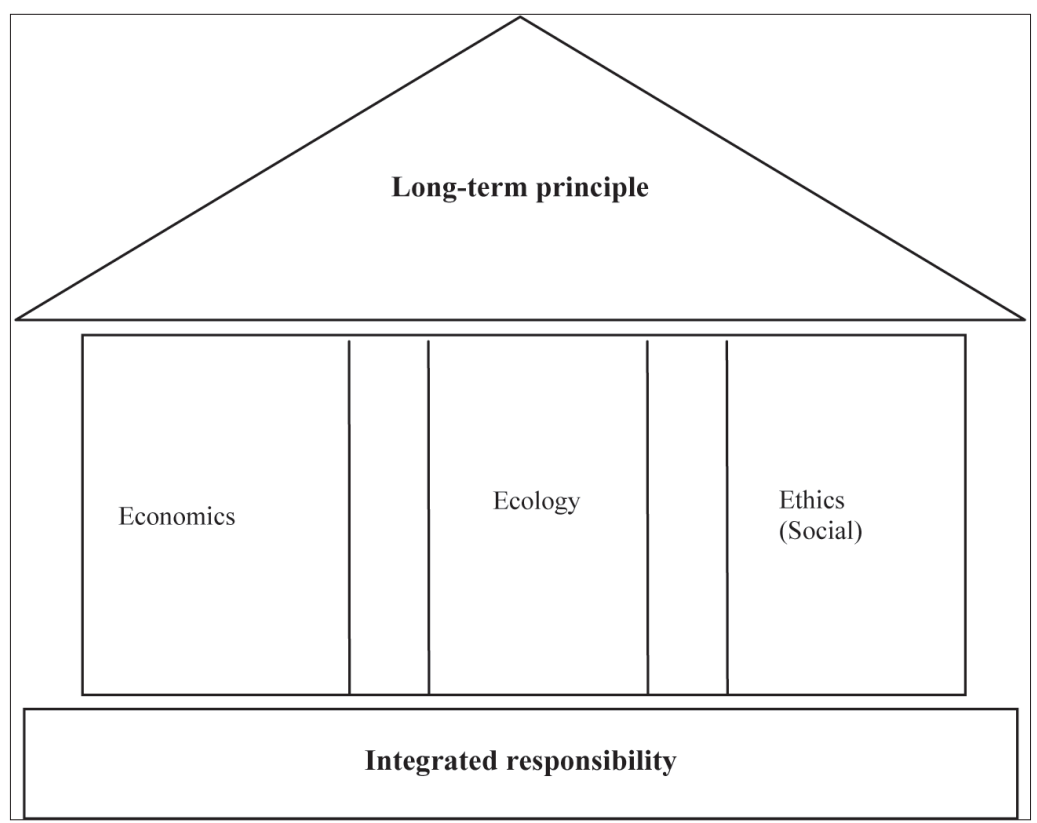

Figure 1. The model of the long-term principle of the integrated responsibility in the integrated coastal zone management strategy

Source: Developed by article author (2006: 13; 2007: 113).

The model of long-term principles can be realistically actualized into strategies for environmental protection and integrated coastal zone management. But unemployed principal concept such long-term practises are enacted, natural resources such as the dunes on the beaches of Palanga (resort of the Baltic Sea, near Klaipeda Sea Port in Lithuania) were damaged by erosion again. Photographs in Figures $2 \mathrm{a}$ and $2 \mathrm{~b}$ show the devastation of erosion following a repeating strong winds (photo by Andrius Pelakauskas).

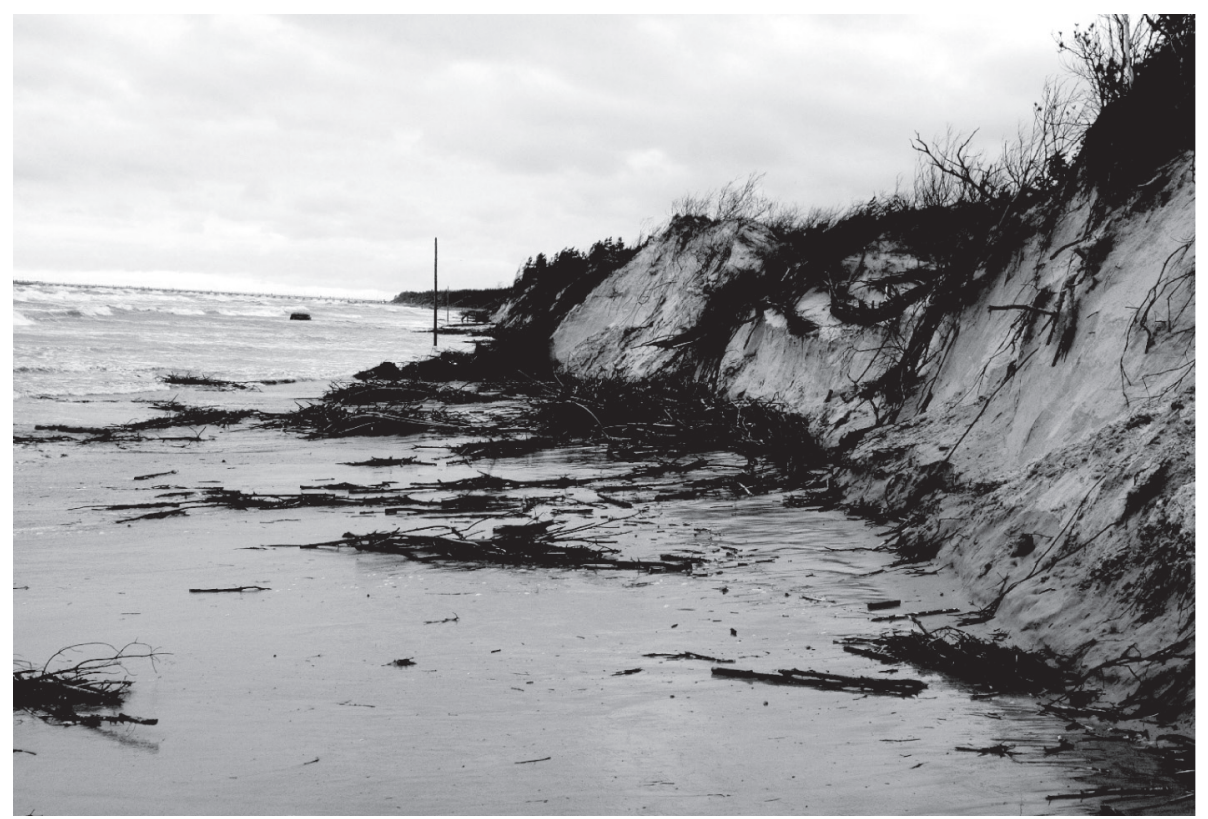

Figure 2a. The beaches of Palanga after repeating strong winds 


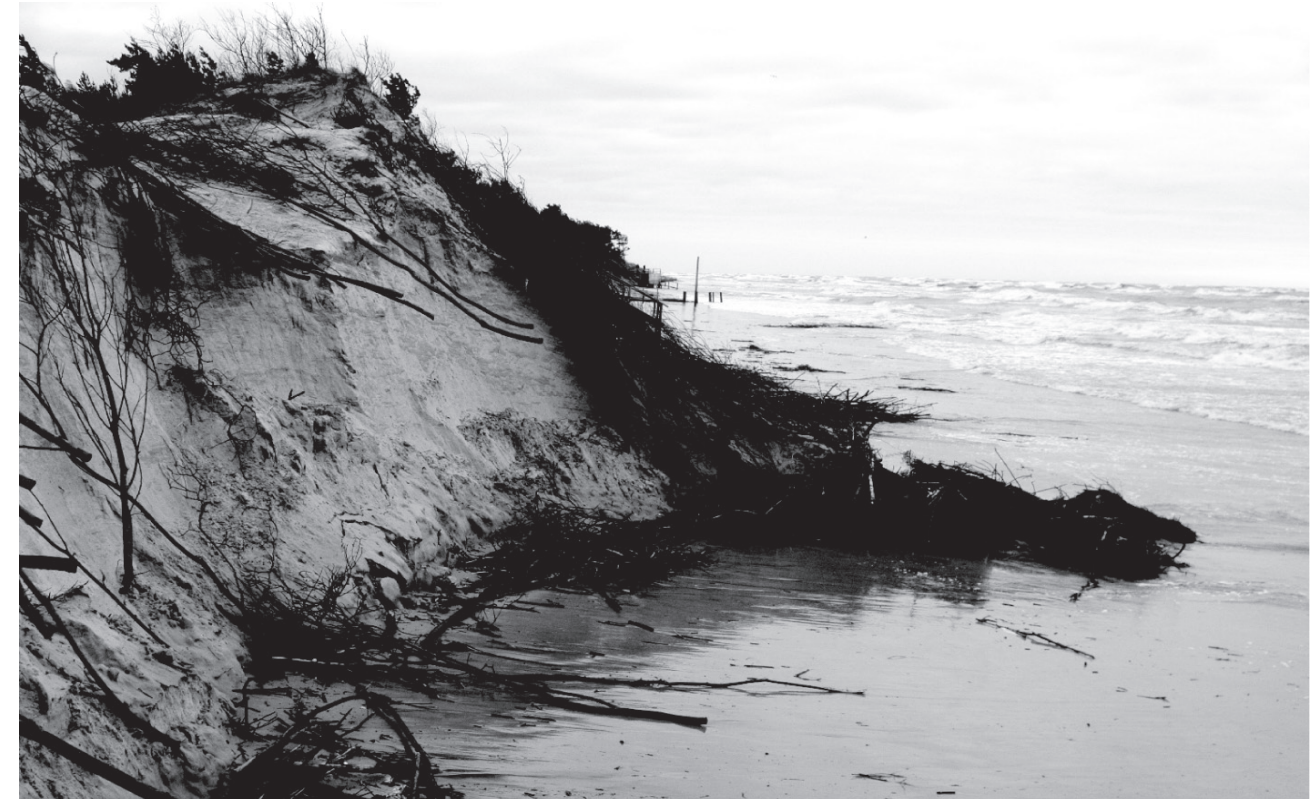

Figure $2 b$. The dunes of Palanga after repeating strong winds

The long-term principle concept is guided by the use of local resources; responsible socio-economic commitments to the possible strategic choices and alternatives, taking into consideration the probabilities of failure; use of various protective measures and technologies; and a vision for multiple timelines according to sustainable development.

3. Key features and definitions of the long-term principle concept for the sustainable development of coastal zone - coastal areas management strategy.

The long-term principle concept for the sustainable development of coastal zone management is based around setting and achieving a vision for the future.

The idea of the long-term principle concept can be presented and analysed according to three key features, where the major statements are:

1. Sustainable development of integrated coastal zone - coastal areas management must begin with an overview of the system as whole, and accurate understanding of management methodology.

2. Thorough investigation into the complex causes and variables in each scenario is essential to proper planning and management of coastal resources.

3. Long-term principles of integrated coastal zone management strategy will effect positive changes that will benefit the future for coastal areas sustainable development.

These key features lead to several questions that must be addressed. First, in scientific terminology, what does "concept" mean? Second, how does the long-term principle concept provide resolution to the problems of integrated coastal zone management? Third, how does this concept of long-term principles impact the future?

For our purposes, a concept (Latin conceptus) refers to the origin of ideas that provides the foundation for further thought. Therefore, the scientific concept is the essential starting point for examining and understanding natural phenomena. It serves as a basis for testing the means and measures used in the sustainable development and planning of coastal zone - coastal areas management.

The concept statement, specifically the concept of long-term principles, has been used by the author of this article in analysing possible strategic choices and considering various alternatives in the planning process, according to Cole (1994) hierarchy by goal - setting activities, which sets the time horizons (long- 
term, mid-term, short-term). Figure 3 demonstrates the author's model of the long-term principle concept for the sustainable development of integrated coastal zone management. Clearly, the model demonstrates that long-term principles of coastal zone - coastal areas management involve a various complex elements and definitions.

1. Mission refers to the sustainable development of short-term projects intended to address current coastal zone management issues.

2. Establishing a vision provides confidence in the methods, means, and operational techniques implemented to reach various goals and objectives. The vision further ensures that proven methods and appropriate technologies are utilized.

3. Timelines (short-term, mid-term, and long-term) help developers maintain priorities as they make strategic choices among alternate approaches.

4. Strategic alternatives consist of the hierarchy of plans (annual plan, long-range plan, strategic plan) that coincide with established timelines.

This model helps to identify the links between the different priorities expressed in purpose, goals and objectives, as well as the conflicts of opinion between scientists and practicians as they seek to develop coastal zone management strategies. Essentially, this model consists of the primary elements necessary for the sustainable development of long-term policies for coastal zone - coastal areas management strategy. These elements can be summarized as follows:

1. The mission establishes short-term, annual plans.

2. The vision encompasses both long-range and strategic planning within the timelines of either longterm or mid-term plans. The goals and objectives of long-range and strategic plans are founded on the principles of long-term management.

The goal of the mission is to establish a foundation of strategies that will lead to the establishment of a future vision. The vision, which gives long-term structure to goals, objectives and measures, is intended to motivate state bodies, scientists, public bodies, coastal project and planning managers to evaluate the socioeconomic and environmental effects of solving coastal problems.

The mission and vision of the long-term principle concept can be well thought-out in advance in order to avoid methodological and technological mistakes, or complicated situations where coastal projects and plans fail to materialize.

The timelines at each level have considerably wide margins, and specific time allowances, especially in terms of new coastal protection and conservation projects, will vary greatly depending on the nature of the project.

The purpose of this article was to provide an understanding of the planning process in sustainable development for coastal zone - coastal areas management strategy, setting forth a hierarchy of timelines along which to structure goals and objectives. Brief working definitions and illustrations in this paper demonstrate how various plans can be organized in order to provide not only short-term mission, but long-term vision.

\section{Conclusions}

The final working definition of the long-term principle concept for the sustainable development of coastal zone - coastal areas management strategy can be used as a benchmark in order to focus attention more on economic effectiveness, rather than on cost reduction. Being focused on effectiveness, scientists, engineers, planners and managers can utilize their understanding of advancements in science and technology, as well as social and economic aspects in order to identify the most suitable technologies, to develop appropriate competitive alternatives, to align with global, European, national or local levels/values, and to allocate resources (i.e. funds, people and heritage coasts) to maximum effect.

The creation of a suitable financial plan, along with procedures for monitoring the progress of environmental protection provides an effective investment process that is able to meet the requirements of the 


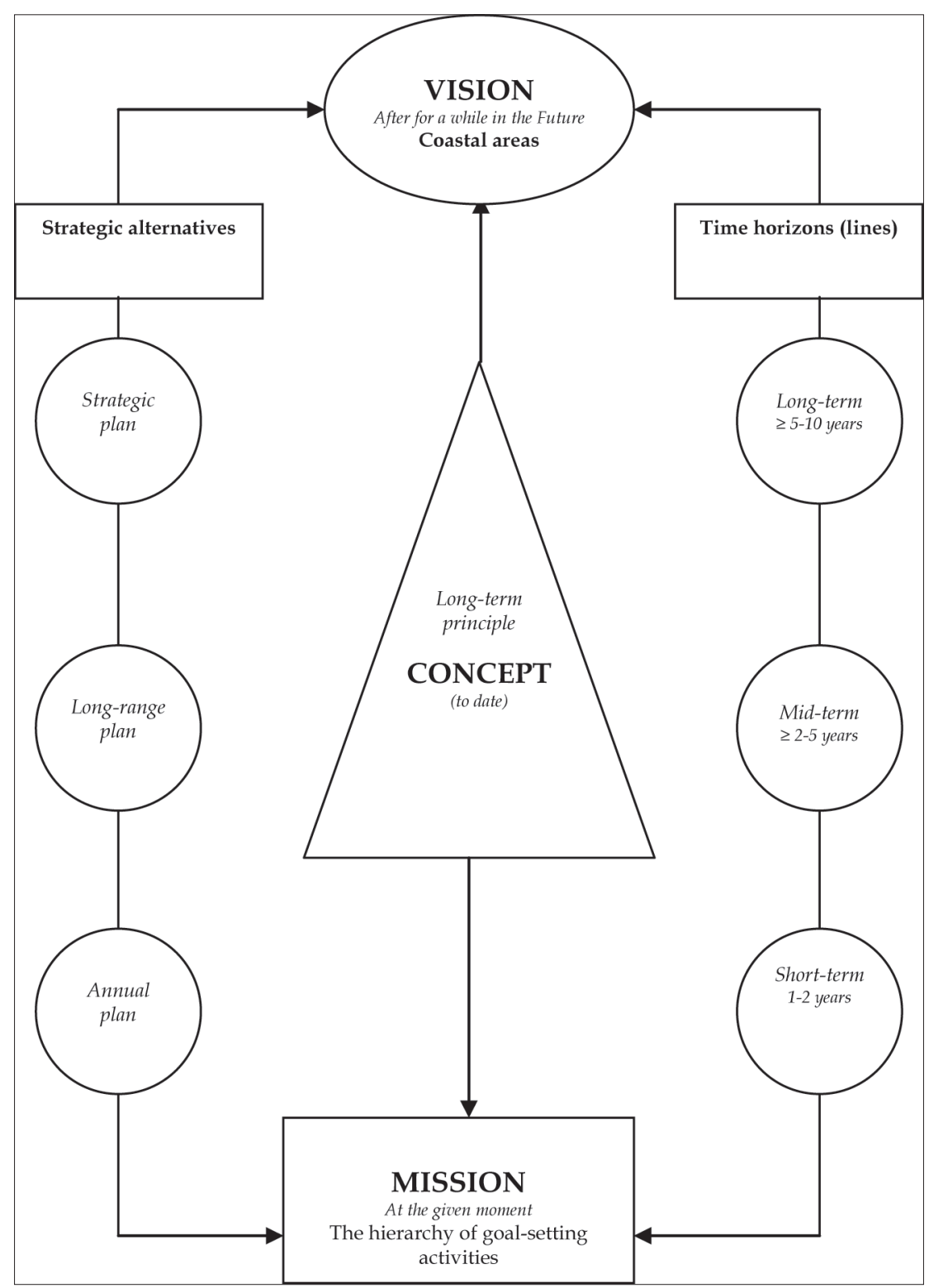

Figure 3. Model of the hierarchy of goal-setting activities of the long-term principle of coastal zone coastal areas management for sustainable development

Source: Composed by author of this article (2007: 111-114).

long-term principle concept. It is possible to end the discussion here regarding the sustainable development of integrated coastal recognizes the importance of understanding the system as a whole, and planning for the future through long-term principles.

\section{References}

Brunsden, D. (1999). Dorset Coast Strategy. Dorset Coast Forum. UK.

Coastal Areas Socio-economic Value, Tourism and Recreation. (2006). Ed. A. Tubielewicz. Gdansk: EUROCAST LITTORAL'2006.

Coastal Innovations and Initiatives. (2006). Eds. M. Forkiewicz, A. Tubielewicz. Gdansk: EUROCAST - LITTORAL'2006. Cole, G. A. (1994). Strategic Management. London: Aldiner Place.

Communication from the Commission to the Council and the European Parliament on Integrated Coastal Zone Management: A Strategy for Europe. (2000). European Commission. COM 2000547 Final. Brussels. 
Gomes, F. V., Pinto, F. T., Neves das L., Sena, A., Ferreira O. (eds.) (2005). Proceedings of the First International Conference on Coastal Conservation and Management in the Atlantic and Mediterranean (ICCCM'05). Portugal: Algarve.

Goodhead, T., Johnson, D. (eds.) (1996). Coastal Recreation Management. The Sustainable development of maritime leisure. London, UK: E\&FN Spon.

Herrier, J. L., Mees, J., Salman, A., Seys, J., Van Nieuwenhuyse, H., Dobbleaere, I. (eds.) (2005). Proceedings 'Dunes \& Estuaries 2005' - International Conference on Nature Restoration Practices in European Coastal Habitats. Koksijde, Belgium. VLIZ Special Publication 19.

Hoffman,W. M., Moore, J. M. (1990). Business Ethics. New York. USA: Mc Graw-Hill Publishing Company, Inc.

Johnson, D. (1996). Coastal management plans. Coastal Recreation management. London: Chapman and Hall, p. $273-295$.

Kotler, Ph., Amstrong, G., Sounders, S. F., Wong, V. (2001). Principles of Marketing. $3^{\text {rd }}$ European ed. Prentice Hall.

Miller, M. C., Cogan J. (eds.) (1997). Coastal Zone'97. The Next 25 years. Conference Proceedings. Volume 1-2. Boston, Massachusetts.

New Approach to Harbour, Coastal Risk Management and Education. (2006). Ed. M. Forkiewicz. Gdansk: EUROCAST LITTORAL'2006.

Philosophical history of the Middle Ages. (1980). A. Rybelis (Editor-in-Chief). Vilnius, Lithuania: Mintis.

Pickaver, A., Salman, A. (2006). Integrated coastal management- do we really have choice? Vol. 15, No. 1/2.

Pickering, H. (1996). Limitation for coastal recreation. Coastal Recreation Management. London: Chapman and Hall, p. 69-91.

Taussik, J. (1996). Planning and the provision of marine recreation facilities. Coastal Recreation management. London: Chapman and Hall, p. 115-137.

Taussik, J., Michel, J. (1996). Partnership in Coastal Zone Management. Cardigan, UK: Samara Publishing Limited.

Vitkiene, E. (2005a). Integrated Quality Management Coastal Recreation and Tourism Business Destinations Strategy. Proceedings of the First International Conference on Coastal Conservation and Mangement in the Atlantic and Mediterranean: Instituto De Hidraulica. Porto, Portugal, p. 503-510.

Vitkiene, E. (2005b). Socioeconomic Responsibility Problems of the Coastal Areas Regional Management under the European Economic Integration. Tiltai (Humanities and Social Sciences), Nr. 3(32), p. 89-95. Klaipeda University, Lithuania.

Vitkiene, E. (2005c). The Role of EU Regional Policy on the ethical responsibility for the development of recreation and tourism an conservation of European coastal habitats'. Dunes and Estuaries: Proceedings International Conference on Nature Restoration Practises in European Coastal Habitats. Ostende, Belgium: Flanders, Marine Institute, p. $675-677$.

Vitkienè, E. (2006). Socio-economic Responsibility of the ICZM. Development. Coastal Areas, Socioeconomic Value, Tourism and Recreation. Gdansk: EUROCAST - LITTORAL'2006, p. 9-15.

Vitkienè, E. (2007). Long-term principle concept for development of coastal zone management. Book of Abstracts of the 2nd International Conference on Coastal Conservation and Management. Tunisia: NOUHA EDITIONS, p. 111-114.

\section{ILGALAIKIO PRINCIPO, KAIP DARNIAI VALDYTI PAJÜRIOZONĄ, KONCEPTAS}

ELENA VITKIENĖ

Klaipèdos universitetas (Lietuva)

\section{Santrauka}

Ilgalaikio principo konceptas paremtas pajūrio zonos valdymo ateities vizijos kūrimu ir jos igyvendinimu. Pajūrio zonos darnaus vystymosi valdymo vizija apima naujausių mokslo, techninių, socialinių ir ekonominių laimèjimų taikymą. Pajūrio gamta, kopos ir paplūdimiai yra išskirtiniai gamtos ištekliai. Jų gyvūnija, kultūriniai, istoriniai ir archeologiniai ištekliai turi būti išsaugoti ateities kartoms tokios pat ar geresnès būklès nei yra šiandien. Ilgalaikio valdymo principas gali būti analizuojamas pagal šias koncepcijas (ekonomikos, ekologijos, etikos): sisteminė apžvalga, detalus problemų sprendimas ir valdymo veiksnių, kurie galètų pagerinti ateiti, numatymas.

PAGRINDINIAI ŽODŽIAI: pajūrio zona, integruota socioekonomine atsakomybé, ilgalaikio principo konceptas, darnus vystymasis. 